\title{
溶融Zn-5〜30mass\%AI合金めっきにおける 合金層成長挙動
}

\author{
内田 幸夫*・山川 宏二*2
}

Growth Behavior of Alloy Layer in Hot-dip Zn-5 30 mass\% Al Coating

Yukio Uchida and Koji Yamakawa

Synopsis : The growth of the alloy layer formed in a hot-dip $\mathrm{Zn}-5 \sim 30$ mass\% Al coating has been studied by gas-reducing coating and fluxing coating methods. The growth of the alloy layer occured at a bath temperature above $520^{\circ} \mathrm{C}$ even in a short time immersion ( $1 \sim 5 \mathrm{~s}$ ), and is accelerated with increasing the $\mathrm{Al}$ content in the bath and raising the bath temperature. The grown alloy layer consists of $\mathrm{Al}-\mathrm{Fe}$ intermetallic compounds (mainly $\mathrm{Al}_{5} \mathrm{Fe}_{2}$ phase containing $6.7 \sim 7.8$ at $\% \mathrm{Zn}$ ), and $\mathrm{Zn}$ phase $(94 \sim 95 \mathrm{at} \% \mathrm{Zn})$ solidified at cavities in $\mathrm{Al}-\mathrm{Fe}$ intermetallic compounds. In similar to $\mathrm{Al}_{5} \mathrm{Fe}_{2}$ phase formed in a hot-dip aluminizing, this $\mathrm{Zn}$-containing $\mathrm{Al}_{5} \mathrm{Fe}_{2}$ phase formed in the hot-dip $\mathrm{Zn}-5 \sim 30$ mass\% $\mathrm{Al}$ coating has also a strong orientation of (002) plane and grows even in a vertical direction to the steel surface. However, in the hot-dip $\mathrm{Zn}-5 \sim 30$ mass\% $\mathrm{Al}$ coating, Al-Fe intermetallic compounds grow preferentially at ferrite grain boundaries of the steel substrate where $\mathrm{Zn}$ has diffused.

It is considered that the grain boundary diffusion of $\mathrm{Zn}$ to the steel substrate has a great influence on the growth of the alloy layer.

Key words : hot-dip coating ; $\mathrm{Zn}-\mathrm{Al}$ coating ; Ti added IF steel ; alloy layer ; Al-Fe intermetallic compounds ; $\mathrm{Al}_{5} \mathrm{Fe}_{2}$; grain boundary ; diffusion; grain boundary diffusion.

\section{1. 緒言}

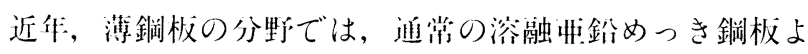
り耐食性に優れた浴融 $\mathrm{Zn}-\mathrm{Al}$ 今金めつき銅板が注目きれてい る。现在, 「業化されているものには浴融Zn-5mass\%Al合 金めっき鎆板と浴融Zn-55mass\% Al-1.5mass\%Si合金めつ き鋼板がある。また，加にしした銅材を熱漬溶融州鉛めっき 寸る分野でも, 浴融Zn-Al介食めっきが月いられ始めている。

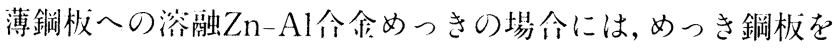

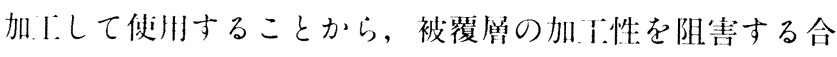

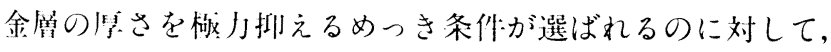
熱漬浴融 $\mathrm{Zn}-\mathrm{Al}$ 合金めつきの場命には, 厚めつき付着量を得 るために合金屏を打く成垓させるめつき条件が選ばれる。

アルミニウムを 5 15mass\%会有する溶融 Zn-Al合金め つきでは，めっき浴温が $500^{\circ} \mathrm{C}$ 超えると非常に短時間で合

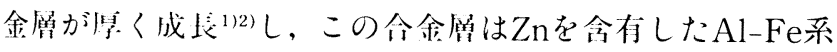

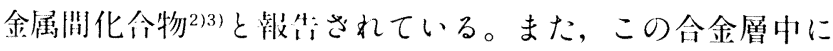
はZn-rich相が散在吉る ${ }^{24)}$ という派然もある。しかし，合金 層の成长学動については必ずしも卜分には解明されていな い。

そこで，アルミニウム濃度が 5 ～30mass \%の溶融 Zn-Al
合金めっきにおける短時間浸せき下での合金層成長挙動を 検討した結果, 興味ある知見が得られたので報告する。

\section{2. 実験方法}

\section{$2 \cdot 1$ 供試材}

実験に供しためつき母材は転炉溶製，連続鋳造，熱間圧 延, 冷間圧延の各工程を経た工場生産の極低炭素Ti添加鋼 (板厚；0.6mm)で，その化学成分值は，C；0.0034, Si； 0.012, Mn;0.13, P;0.011, S;0.008, sol. Al；0.026, $\mathrm{Ti} ; 0.083$ (以上, mass\%)である。溶融 $\mathrm{Zn}-\mathrm{Al}$ 合金めっき には，40mm幅 $\times 150 \mathrm{~mm}$ 長さ（ガス還元めっき用）および $80 \mathrm{~mm}$ 幅 $\times 250 \mathrm{~mm}$ 長さ（フラックスめっき用）に切り出し た短冊状試騟片を用いた。

\section{$2 \cdot 2$ 溶融Zn-AI合金めっき}

溶融 $\mathrm{Zn}-\mathrm{Al}$ 合金めつきはガス還元型溶融めっき装置 ${ }^{5}$ を用 いたガス還元めっき法と塩化アンモニウム・塩化亜鉛の混 合水溶液を用いたフラックスめっき法で行った。ガス還元 めっきでは, 試験片を $50 \mathrm{vol} \% \mathrm{H}_{2}-\mathrm{N}_{2}$ 雲囲気中で $780^{\circ} \mathrm{C}$, 均 熱30sの条件で還元加熱した後, 板温がめっき浴温と同一に なった時点で同じ雲讲気下に置かれためっき浴に浸せきし，

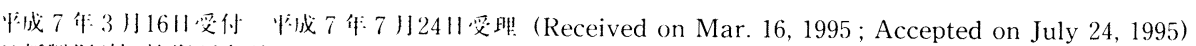

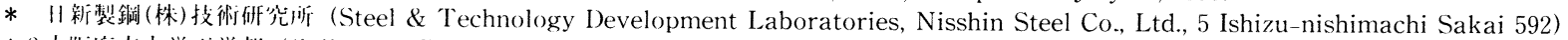

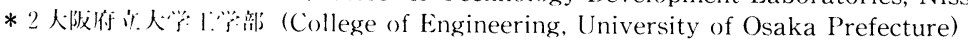


引き上げてめっき試片とした。浸せき時間は試験片がめっ き浴に入った時点をゼロとして設定した。めっき後の泠却 は板温； $350^{\circ} \mathrm{C}$ までの平均冷却速度を $5{ }^{\circ} \mathrm{C} / \mathrm{s}$ に調整した。

フラックスめっきでは，ガス還元型めっき装置にて，上 記条件で還元焼鈍だけを行った試験片を用いた。試験片は アルカリ脱脂, 酸洗 $(15 \mathrm{vol} \% \mathrm{HCl}$, 常温) 後, 塩化アンモ ニウム $(4.6 \mathrm{mass} \%)$ と塩化亜鉛 $(20.4 \mathrm{mass} \%)$ との混合

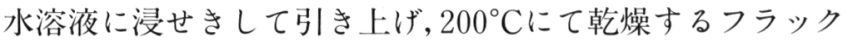
ス処理を施した。そして，めっき浴に浸せきし，引き上げ てめっき試片を作製した。フラックスめっきでは，フラッ クスの分解に伴う白煙が上がった時点をゼロとして浸せき 時間を設定し，めっき後は直ちに水冷（平均冷却速度；約 $\left.1,000^{\circ} \mathrm{C} / \mathrm{s}\right)$ した。

溶融 $\mathrm{Zn}-\mathrm{Al}$ 合金めっき浴は，電気亜鉛地金 (99.99mass\% Zn）と純アルミニウム地金（99.99mass\%Al）にて，あら かじめAl濃度が 5,15 おび30mass\%の調合地金を作製し てガス還元めっきとフラックスめっきに供した。なお，め っき浴にFeは添加していない。

\section{$2 \cdot 3$ 合金層の分析}

合金層の光学顕微鏡観察および走査電子顕微鏡 (SEM) 観察はめっき試片起断面方向に研磨した後, $0.3 \mathrm{vol} \%$ ナイタ ールでエッチングして行った。また，一部のめっき試片に ついては, $3 \mathrm{vol} \% \mathrm{HNO}_{3}$ 溶液中に浸せきしてめっき層を溶解 除去した後，研磨し，ノーエッチングにて合金層を観察し た。

合金層の厚さは, 400倍の光顕観察で得られた一視野内の 合金層を図形平均化して測定し, 全10視野の测定値の平均, 最大，最小で表示した。

合金層の分析には，波長分散型およびエネルギー分散型 X線マイクロアナライザー（XMA）を用いた。さらに微小 部の分析には，フィールドエミッション型スキャニング・ オージェ・マイクロ分析装置（FE-SAM，アルバックファ イ(株), Model-670) を用いた。また，上記方法にてめっき
層を溶解除去した試片についてはX線回折装置（Cu管球, $50 \mathrm{kV}-150 \mathrm{~mA}$ ）により金属間化合物の同定を行った。

\section{3. 実験結果}

\section{$3 ・ 1 \quad$ 合金層成長におよぼすめっき浴温および めっき浴中のAl濃度の影響}

Fig. 1 に，ガス還元めっき法で溶融めっきしたZn-5, 15 および30mass\%Al合金めっき（浸せき時間； $5 \mathrm{~s}$ 一定）の被 覆層断面組織を示す。

$\mathrm{Zn}-5 \mathrm{mass} \% \mathrm{Al}$ 合金めっきの場合, 浴温 ; $480^{\circ} \mathrm{C} て ゙ は$ 鋼素 地とめっき層界面が非常に平滑であり, 非成長型の薄い合 金層が形成されていることが窅える。これに対して, 浴温； $520^{\circ} \mathrm{C}$ よび $550^{\circ} \mathrm{C} て ゙ は$ 鋼素地とめっき層界面に成長型の合

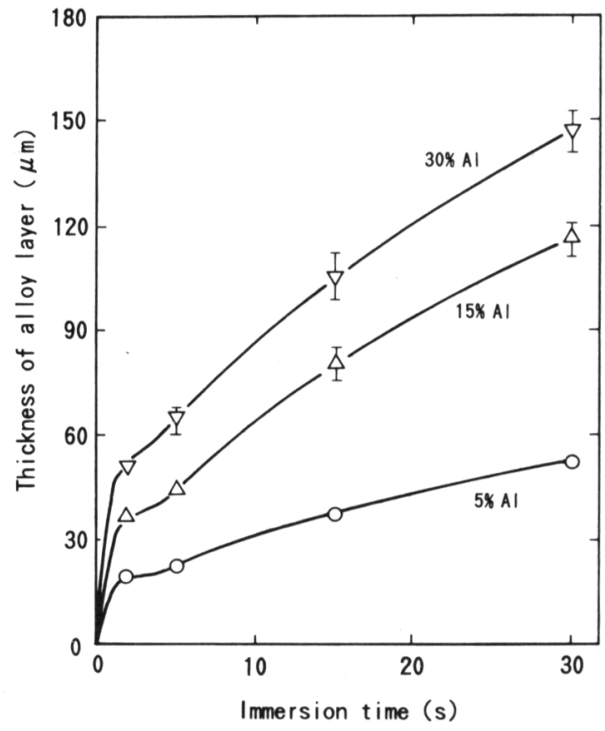

Fig. 2. Effects of immersion time and $\mathrm{Al}$ content in bath on alloy layer growth in hot-dip $\mathrm{Zn}-5$ $\sim 30$ mass\% Al coating. method, Bath temp.; $550^{\circ} \mathrm{C}$ )

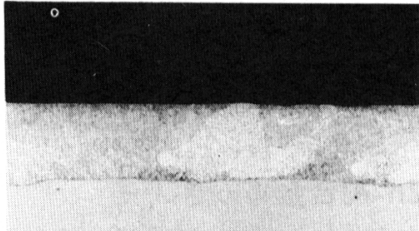

a) $\mathrm{Zn}-5 \mathrm{KAl}$, bath temp. $=480^{\circ} \mathrm{C}$

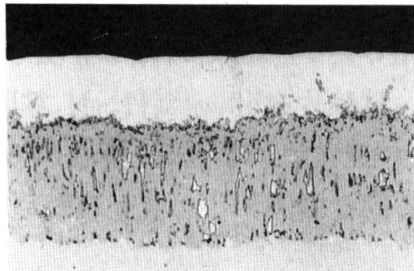

d) $\mathrm{Zn}-15 \% \mathrm{Al}$, bath temp. $=520^{\circ} \mathrm{C}$

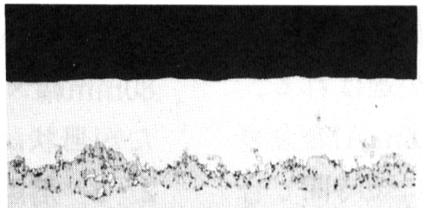

b) $\mathrm{Zn}-5 \% \mathrm{Al}$, bath temp. $=520^{\circ} \mathrm{C}$

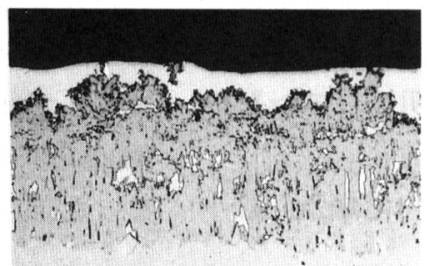

e) $\mathrm{Zn}-15 \% \mathrm{Al}$, bath temp. $=550^{\circ} \mathrm{C}$

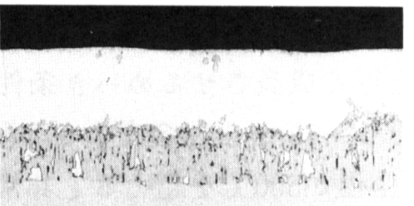

c) $\mathrm{Zn}-5 \% \mathrm{Al}$, bath temp. $=550^{\circ} \mathrm{C}$

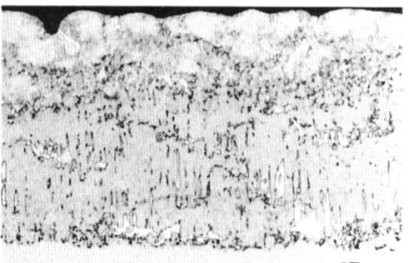

$25 \mu \mathrm{m}$

f) $\mathrm{Zn}-30 \% \mathrm{Al}$, bath temp. $=550^{\circ} \mathrm{C}$

Fig. 1. Cross-sections of hot-dip $\mathrm{Zn}-5,15$ and 30 mass\% $\mathrm{Al}$ coatings obtained at vaious bath temperatures. (Gas-reducing method, Immersion time ; $5 \mathrm{~s}$ ) 
金層の形成が認められ，めっき浴温が高い方が厚く成長し ている。同様に, 浴温 $; 520^{\circ} \mathrm{C} よ ひ ゙ 550^{\circ} \mathrm{C} て ゙$ 溶融めっきし

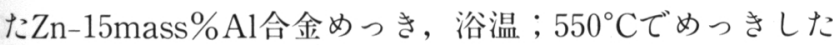
Zn-30mass\%Al合金めっきでも成長型合金層の形成が認め られる。そして,いずれのAl濃度の溶融 $\mathrm{Zn}-\mathrm{Al}$ 合金めっきと も，この成長型合金層の中に白色の相が散在している。き らに広い範囲で合金層の成長程度を観察すると，合金層が 比較的厚く成長している箇所と成長が遅れている箇所が周 期的に存在している。このような合金層を図形平均化して 浴温； $550^{\circ} \mathrm{C} て ゙ の$ 合金層成長におよぼす浸せき時間および浴 中Al濃度の影響を整理した結果をFig. 2 に示す。困から, 同 じめっき浴温でも浴中のAl濃度が高くなるほぼ合金層の成 長が著しいことがわかる。しかし, Al濃度が 5 mass\%から 15 mass\%に増加した時の成長速度上昇の方か 15 mass\%から 30 mass\%に増加した時の成長速度上昇より大きい。

\section{$3 \cdot 2$ 成長型合金層の組成と構造}

実験では, Zn-5, 15および30mass\%Al合金めっきの被覆 層それぞれについて検討を行ったが，いずれのめっきとも 合金層組成ならびに構造に大きな差異は認められなかった ので，以下，Zn-15mass\%Al合金めっきの合金層について の結果を代表として記述する。

Fig. 3 およびTable 1 は, ガス還元めっき法とフラックス めっき法 (めっき後, 水冷) で得られたZn-15mass\% Al合 金めっきの被覆層断面のSEM像と Fig. 3 中の各位置におけ るXMA分析結果を示す。

ガス還元めっきで得られた成長型合金層 (Fig. 3 (a) 中の 黒い部分) は, Znt6.7〜8.7at\%含有したAl-Fe系金属間化 合物 (以下, $\mathrm{Al}-\mathrm{Fe} \cdot \mathrm{IMC}$ と記す) で，鋼素地側でFe濃度が 高く, めっき層と接する側でFe濃度が低くなる濃度勾配を 有している。XMA分析による $\mathrm{Al} /(\mathrm{Al}+\mathrm{Fe})$ 比率から,その 主相は $\mathrm{Al}_{5} \mathrm{Fe}_{2}$ に相当している。Fig. 1 の顕微鏡観察で成長型
Table 1. Results of XMA analysis of alloy layer in hot-dip $\mathrm{Zn}-15$ mass\%Al coating. (at\%)

\begin{tabular}{crrrccrccc}
\hline (a)Gas-reducing method & \multicolumn{4}{c}{ (b)Fluxing method(water-quenched) } \\
\hline Position* & $\mathrm{Al}$ & $\mathrm{Fe}$ & $\mathrm{Zn}$ & $\mathrm{Al} /(\mathrm{Al}+\mathrm{Fe})$ & Position $^{*}$ & $\mathrm{Al}$ & $\mathrm{Fe}$ & $\mathrm{Zn}$ & $\mathrm{Al} /(\mathrm{Al}+\mathrm{Fe})$ \\
1 & 61.6 & 30.2 & 8.2 & $67.1(\%)$ & 1 & 62.6 & 29.3 & 8.1 & $68.2(\%)$ \\
2 & 0.9 & 95.8 & 3.3 & - & 2 & 0.9 & 95.9 & 3.2 & - \\
3 & 65.5 & 26.1 & 8.4 & 71.5 & 3 & 64.6 & 26.7 & 8.7 & 70.7 \\
4 & 0.8 & 4.1 & 95.1 & - & 4 & 1.8 & 3.7 & 94.3 & - \\
5 & 65.7 & 27.4 & 6.9 & 70.6 & 5 & 65.7 & 25.6 & 8.7 & 71.9 \\
6 & 61.7 & 18.9 & 19.4 & 76.6 & 6 & 62.6 & 18.3 & 19.1 & 77.34 \\
\hline
\end{tabular}

*positions shown in Fig. 3 (a) and (b).

合金層中に散在していた白色相 (Fig. 3 (a) 中の 4 の位置に 相当) は，Al $\mathrm{A} F \mathrm{Fe}$ 数at\%含むZnで，そのAl濃度はめっき 浴組成と比べて著しく低下している。同条件で溶融めっき し，めっき後水冷したフラックスめっき材の合金層はガス 還元めっき法で得られた合金層より厚さが薄いものの, こ の合金層も $\mathrm{Al}-\mathrm{Fe} \cdot \mathrm{IMC} て ゙ ， そ の$ 主相は $\mathrm{Al}_{5} \mathrm{Fe}_{2}$ に相当してい る。また，この合金層中にもガス還元めっき材の合金層中 に見られた白色相が散在 (Fig. 3 (b) 中の 4 の位置) し，そ の組成もガス還元めっきの場合と大きな差異はない。

さらに特筆すべきことは合金層と鋼素地界面の形態で, $\mathrm{Al}-\mathrm{Fe} \cdot \mathrm{IMC}$ 鋼素地側に鋭く食い込んでいる箇所, 鋼素地 が合金層側に突出している筒所や鋼素地が鱗片状に浮き上 がっている箇所 (Fig. 3 (a) 中の 2 の位置) が無数に観察さ れる。

Fig. 4 およびTable 2 は，ガス還元めっき法で得られた $\mathrm{Zn}-15 \mathrm{mass} \% \mathrm{Al}$ 合金めっき（浴温; $520^{\circ} \mathrm{C}$ ，浸せき時間； $5 \mathrm{~s} ）$ のっき層を $3 \mathrm{vol} \% \mathrm{HNO}_{3}$ 水溶液で溶解した後の合金 層の断面組織と Fig. 4 中の各位置でのXMA分析結果である。

$3 \mathrm{vol} \% \mathrm{HNO}_{3}$ 水溶液で溶解処理した合金層は，若干， $\mathrm{Zn}$ 濃度が低下してはいるものの, $\mathrm{Al} /(\mathrm{Al}+\mathrm{Fe})$ 比率は溶解処理 前の合金層 (Table 1$)$ と差異はなく，合金層の主相はZnを

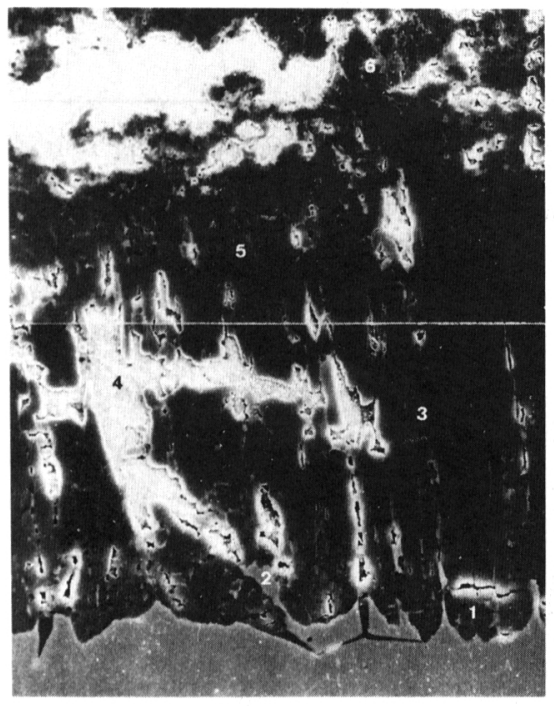

a) Gas reducing method

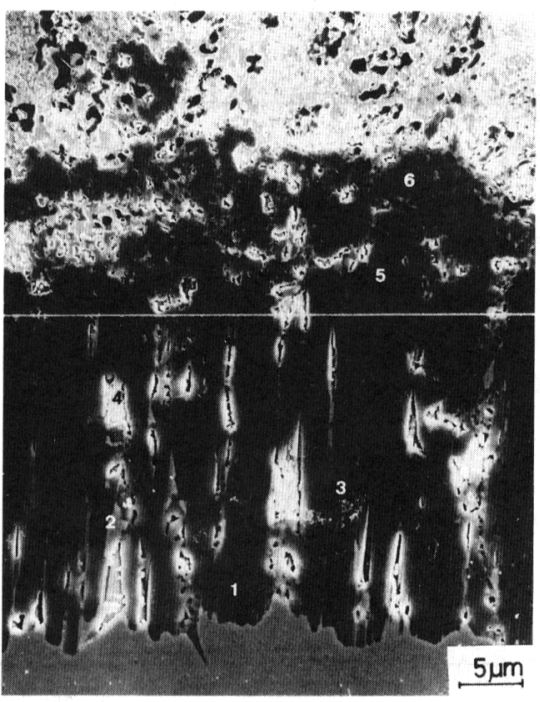

b) Fluxing method(water-quenched)

Fig. 3. Cross-sectional microstructures of $\mathrm{Zn}-15$ mass\% $\mathrm{Al}$ coatings prepared by two hot-dip coating methods. (Bath temp,; $520^{\circ} \mathrm{C}$, Immersion time ; $5 \mathrm{~s}$ ) 
含有した $\mathrm{Al}_{5} \mathrm{Fe}_{2}$ に相当している。この相は鋼板面に対して 垂直に一方向成長し, 個々の結晶は粗大化している。また, めっき層と接する合金層表層部には $\mathrm{Al}_{5} \mathrm{Fe}_{2}$ 相より $\mathrm{Al}$ 濃度の 高い, 細粒な $\mathrm{Al}-\mathrm{Fe} ・ \mathrm{IMC}$ 形成されているのが観察できる。

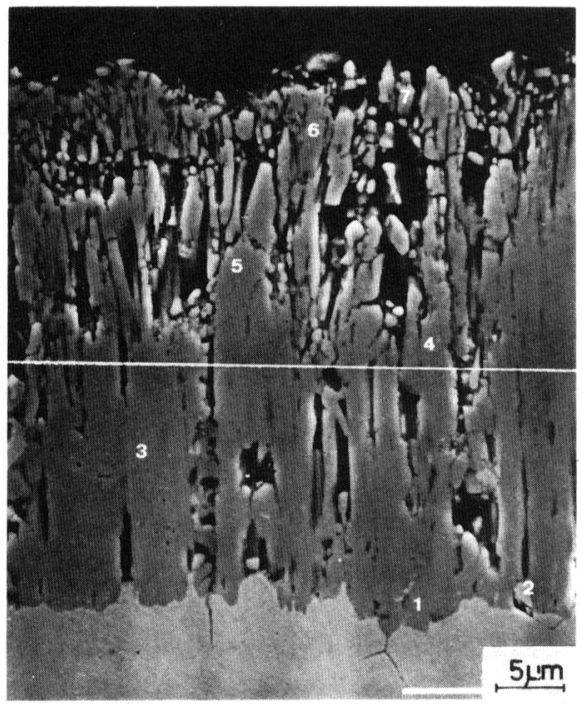

Fig. 4. Cross-sectional microstructure of alloy layer after dissoluving overlay of $\mathrm{Zn}-15$ mass $\% \mathrm{Al}$ coating. (Gas-reducing method, Bath temp.; $520^{\circ} \mathrm{C}$, Immersion time; $5 \mathrm{~s}$ )

Table 2. Results of XMA analysis of alloy layer after dissoluving overlay of $\mathrm{Zn}-15$ mass\% $\mathrm{Al}$ coating. (at\%)

\begin{tabular}{crccc}
\hline Position* & $\mathrm{Al}$ & $\mathrm{Fe}$ & $\mathrm{Zn}$ & $\mathrm{Al} /(\mathrm{Al}+\mathrm{Fe})$ \\
\hline 1 & 63.6 & 32.2 & 4.2 & $66.4(\%)$ \\
2 & 1.7 & 98.0 & 0.3 & - \\
3 & 66.6 & 27.4 & 6.0 & 70.9 \\
4 & 67.7 & 27.1 & 5.2 & 71.4 \\
5 & 69.7 & 26.0 & 4.3 & 72.8 \\
6 & 70.4 & 25.0 & 4.6 & 73.8 \\
7 & 75.3 & 22.0 & 2.7 & 77.4 \\
\hline
\end{tabular}

*Positions shown in Fig. 4.
さらに, Al-Fe・IMC合金層内に散在していたZn濃度の高い 相が3 $\mathrm{vol} \% \mathrm{HNO}_{3}$ 溶解処理で消失していることから,この $\mathrm{Zn}$ 濃度の高い相はバルクのめっき浴と繋がったパスを有して いると判断される。

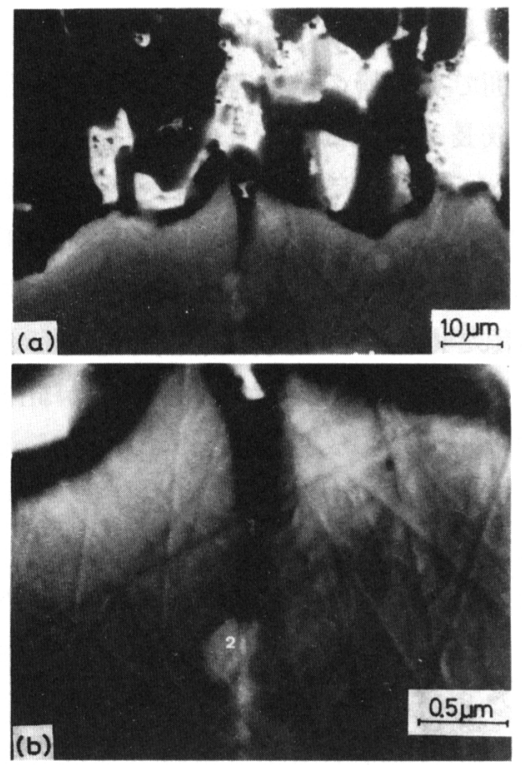

a) at the interface between $\mathrm{Al}-\mathrm{Fe}$. IMC and steel substrate.

b) at the front of wedge-shaped Al-Fe-IMC (enlarged(a)).

Fig. 6. Microstructure at interface between Al-Fe IMC and steel substrate. (Zn-15 mass\% Al coating, Fluxing method, Bath temp.; $520^{\circ} \mathrm{C}$, Immersion time ; $5 \mathrm{~s}$ )

Table 3. Results of FE-SAM analysis at front of wedge-shaped Al-Fe IMC. (at\%)

\begin{tabular}{ccccc}
\hline Position* & $\mathrm{Al}$ & $\mathrm{Fe}$ & $\mathrm{Zn}$ & $\mathrm{Al} /(\mathrm{Al}+\mathrm{Fe})$ \\
\hline 1 & 51.3 & 41.6 & 7.1 & 55.2 \\
2 & 0 & 82.8 & 17.2 & - \\
\hline
\end{tabular}

${ }^{*}$ Positions shown in Fig. 6 (b).

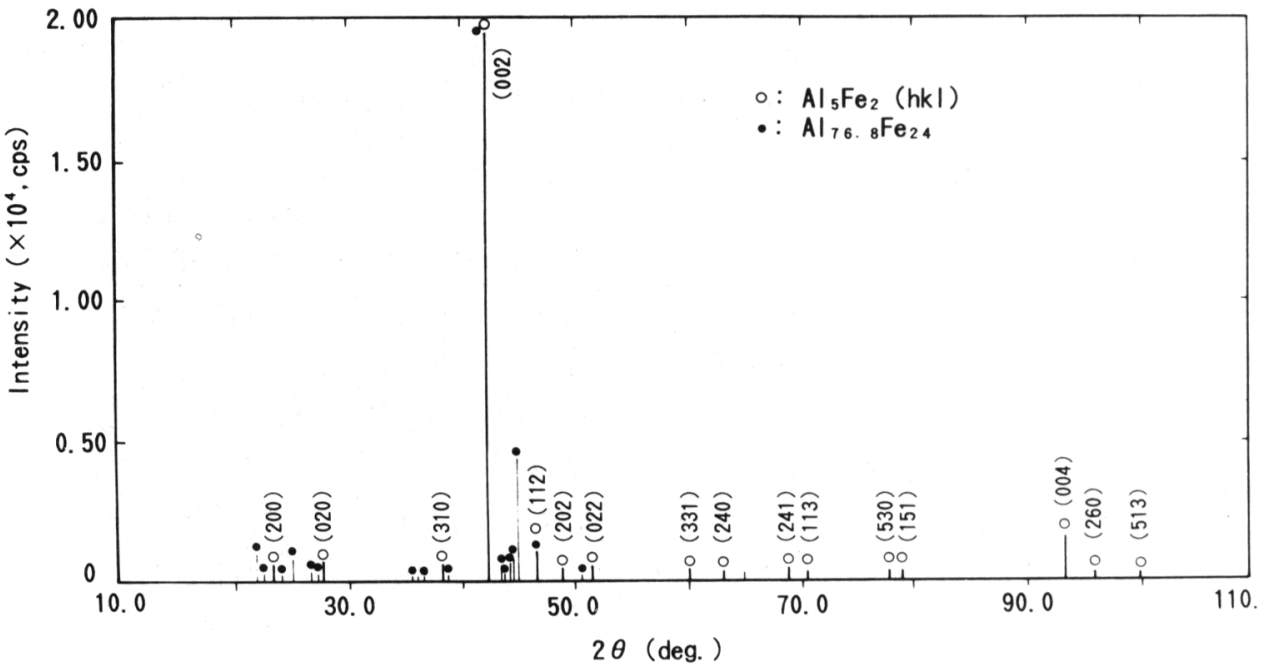

Fig. 5. X-ray diffraction patterns of alloy layer after dissoluving overlay of $\mathrm{Zn}-15$ mass $\% \mathrm{Al}$ coating. (Gas-reducing method, Bath temp ; $520^{\circ} \mathrm{C}$, Immersion time; $5 \mathrm{~s}$ ) 


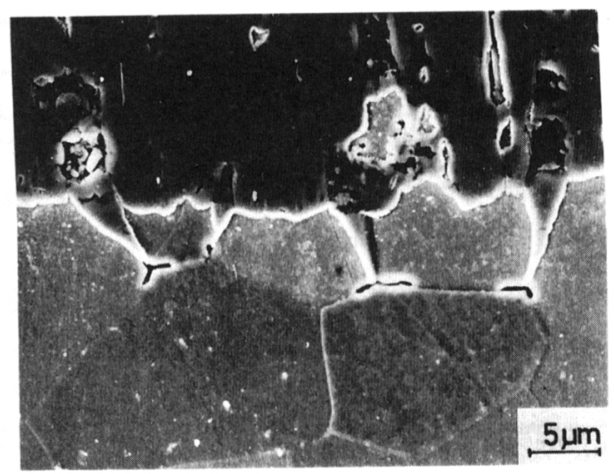

Fig. 7. Penetration of Al-Fe IMC to ferrite grain boundary of steel substrate. (Zn-15 mass\% Al coating, Fluxing method, Bath temp.; 520 ${ }^{\circ} \mathrm{C}$, Immersion time; $5 \mathrm{~s}$ )

めっき層を溶解除去処理したZn-15mass\%Al合金めっき 鋼板の合金層のX線回折結果をFig. 5 に示す。

図から, 斜方晶構造の $\mathrm{Al}_{5} \mathrm{Fe}_{2}$ と笚斜晶構造の $\mathrm{Al}_{76.8} \mathrm{Fe}_{24}$ $\left(\mathrm{Al}_{13} \mathrm{Fe}_{4}\right)$ の回折パターンが得られ, 合金層がこれら 2 相 を主体として構成されていることがわかる。また， $\mathrm{Al}_{5} \mathrm{Fe}_{2}$ 相は，その（002）面に著しい配向在有しており，Fig. 4 の 観察結果と良く合致している。

\section{$3 \cdot 3 \mathrm{Al}-\mathrm{Fe}$ 合金層と鋼素地界面}

Fig. 6 およびTable 3 に, Al-Fe・IMCが鋼素地側に食い込 んでいる筒所のSEM像とその先端部のFE-SAM分析結果を 示す。写真および分析結果から, Al-Fe・IMCが鋼素地側に 鋭く食い込んだ先端には, Znだけが拡散したZn固溶Fe相が 確認できる。また, Fig. 7 に示したように, Al-Fe・IMCが 鋼素地側に食い込んでいる箇所は鋼素地のフェライト粒界 と対応している。なお, Fig. 7 中で, Al-Fe・IMCが鋼素地 側に鋭く食い込んだ先端に空隙が認められるが，これは， フェライト粒界をだす目的で3vol\%ナイタールでエッチング した時にZnが溶解した結果と判断される。

\section{4. 考察}

本実験で得られた溶融Zn-5 30mass\%A1合金めっきの成 長型合金層は, $\mathrm{Zn}$ を6.7 8.7at\%含有する $\mathrm{Al}_{5} \mathrm{Fe}_{2}$ 相を主体 とし, 表層側に $\mathrm{Zn}$ を含有する $\mathrm{Al}_{13} \mathrm{Fe}_{4}$ 相を有する $\mathrm{Al}-\mathrm{Fe} \cdot \mathrm{IMC}$

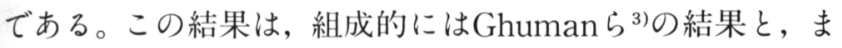
た構造的にはMarquesらうおよびZn-45mass\% Al合金めっき について検討したSelverian ら ${ }^{6)} の$ 結果と合致している。Al, FeおよびZnの原子径にほとんど隔たりがないこと考虑す ると, ZnはAl- $\mathrm{Fe} ・ \mathrm{IMC}$ 中に固溶しているものと判断できる。

そこで, 本系の溶融めっきで得られる Al-Fe・IMC合金層 とこれまでに種々報告されている溶融アルミニウムめっき で得られる $\mathrm{Al}-\mathrm{Fe} \cdot \mathrm{IMC}$ 合金層》 12)の成長挙動を比較してみ る。溶融アルミニウム为っきで形成される合金層は $\mathrm{Al}_{5} \mathrm{Fe}_{2}$ 相が主体で，鋼素地と合金層界面が四凸を有する舌状組織 を呈すること勇 9/が知られている。Heumann ら ${ }^{9 /}$ は, $\mathrm{Al}_{5} \mathrm{Fe}_{2}$
相のC軸方向には多くの欠陥が集まっており，それが成長方 向と一致するので $\mathrm{Al}_{5} \mathrm{Fe}_{2}$ 相が舌状に成長すると報告してい る。溶融Zn-5 30mass\%Al合金めっきで得られる成長型合 金層も，Znt固溶してはいるが $\mathrm{Al}_{5} \mathrm{Fe}_{2}$ 相が鋼板面に対して 垂直に一方向成長していることから，その成長挙動は基本 的には溶融アルミニウムめっきの場合と同じと考光られる。 また, 溶融Zn-Al合金めっきの浴温が同じでも浴中のAl濃度 の高い方が合金層の成長も早いという結果は, 溶融アルミ ニウムめつきの場合 ${ }^{12)}$ と同様, 合金層の成長が $\mathrm{A} 1$ の内方拡 散に支配されていることを支持している。

しかし, 著者ららが以前に検討した結果では, 浴温； $730^{\circ} \mathrm{C}$ の溶融アルミニウム浴に鋼板を30s間浸せきしても，その合 金層は $40 \mu \mathrm{m}$ 程度までしか成長していない。また，他の報 告7)10111)でも, 浴温; $700^{\circ} \mathrm{C} \sim 740^{\circ} \mathrm{C}, 30$ s間の浸せきで $\mathrm{Al}-\mathrm{Fe}$ ・ IMC合金層の厚さは30 100 $\mu \mathrm{m}$ 程度である。これに対して, 溶融Zn-5 30mass\%Al合金めっきでは, 溶融アルミニウム めっきより $150^{\circ} \mathrm{C}$ 以上もめっき浴温が低いにもかかわらず, $\mathrm{Al}-\mathrm{Fe} \cdot \mathrm{IMC}$ 成長が著しい。たとえば，浴温； $550^{\circ} \mathrm{C} の$ Zn-15mass\%Al合金めっきでは, 30s間の浸せきで合金層厚 は $120 \mu \mathrm{m} に も$ 達している。したがって, 溶融Zn-5 30mass \% Al合金めっきでは, 浴中のZnがAl-Fe・IMCの成長を促進 していると理解される。その作用の一つとして, 鋼素地の フェライト粒界へのZnの粒界拡散を挙げることができる。

Fig. 6 斿よびFig. 7 に示されるように,Znの粒界拡散に誘 導されて Al-Fe・IMCが形成されていることから, Al-Fe・IMC の成長がZnの粒界拡散に強く影響されていることは明らか である。現時点では, 何故Znがフェライト粒界へ拡散した 後を追って Al-Fe・IMCが成長するかについては不明である が, Znの融点を超えた温度域でもZnの粒界拡散が早いこと は溶融金属脆化 ${ }^{13)}$ として良く知られている。また, 溶融

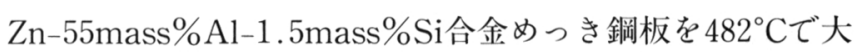
気加熱した時にもZnの粒界拡散による鋼板の脆化が起こる

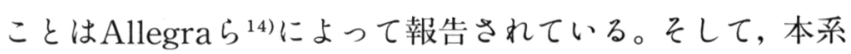
の溶融めっきの場合には, Znの粒界拡散に誘導されて形成 された $\mathrm{Al}-\mathrm{Fe} ・ \mathrm{IMC} に$ 囲まれたフェライト粒は大きな圧縮応 力を受けて上方に引き伸ばされる，あるいは浮き上がるも のと推察される。

$\mathrm{Al}-\mathrm{Fe} \cdot \mathrm{IMC}$ 合金層の成長を促進するもう一つの要因とし て, 合金層中に散在するZn濃度の高い白色相の影響を挙げ ることができる。この相について得られた結果は, 以下の ように整理される。

(1)めつき後の冷却速度に関係なく, 組成はほぼ一定で ある。

( 2 ) Zn濃度は94 95at\%であり, 成長型合金層が形成さ れるめっき浴温では溶融状態にある。

( 3 ) バルクめっき浴と丵がったパスを有している。

これらの結果から，溶融Zn-45mass\%A1合金めっきで形 成された $\mathrm{Al}-\mathrm{Fe} ・ \mathrm{IMC}$ 中のZn-rich相について検討したSelver- 
$\operatorname{ian} 5^{6)}$ の見解と同様, Zn濃度の高い白色相はめっき浴中に 鋼板を浸せきしている段階で，成長する $\mathrm{Al}-\mathrm{Fe} ・ \mathrm{IMC}$ 空腺 に溶融状態で存在し, めっき後の冷却過程で晶出したと理 解できる。

この白色相の晶出位置は, Fig. 3 に示されるような鋼素地 が突出した箇所の上側と Fig. 3 (a)の右下に観察されるよう な $\mathrm{Al}-\mathrm{Fe} ・ \mathrm{IMC} に$ の場合には, 鋼素地のフェライト粒界での Al-Fe・IMCの優 先成長により個々の Al-Fe・IMC結晶に成長速度差が生じて 空隙が形成されると推察される。また，Al-Fe・IMCにクラ ックが入った箇所は，その周囲の $\mathrm{Al}-\mathrm{Fe} ・ \mathrm{IMC}$ 成長に伴っ てクラックの上側の $\mathrm{Al}-\mathrm{Fe} \cdot \mathrm{IMC}$ 持ち上げられ，大きな空 隙が形成され，そこにバルクのめっき浴が多量に侵入する と判断される。そして, Al-Fe・IMC中の空隙に入り込んだ バルク組成の融液から $\mathrm{Al}$ が鋼素地側に拡散し, 融液中の $\mathrm{Al}$ 濃度は著しく低下することになる。

$\mathrm{Al}-\mathrm{Fe} \cdot \mathrm{IMC}$ 中のクラックは, $\mathrm{Al}-\mathrm{Fe} \cdot \mathrm{IMC}$ 鋼素地界面の 剪断応力により発生すると考えられる。仮に, Znが鋼素地 のフェライト粒界に拡散した後を追ってAlが一方的に拡散 し, Al-Fe・IMCとしてAlFe相が形成されたとする。AlFe 相は, $\mathrm{Al}$ と Feがそれぞれ 1 原子で単位セル体積は $2.47 \times 10^{-2}$ $\mathrm{nm}^{3}$ であるのに対して, Fe相は $\mathrm{Fe}$ ； 2 原子で単位七ル体積 が2. $34 \times 10^{-2} \mathrm{~nm}^{3}$ であるから,鋼素地側にAlFe相か形成され ると約 2 倍の体積膨脤が起こることになる。実際には，鋼 素地に鋭く食い込んでいる Al-Fe・IMCがAlFe相だけから成 っているわけではないが，いずれにしろ Al-Fe・IMCとの界 面の鋼素地は著しい歪みを受けた状態になると判断される。 一方, $\mathrm{Al}-\mathrm{Fe} \cdot \mathrm{IMC}$ はビッカース硬度が500程度の硬く,かつ 脆い相であるので, 鋼素地が歪んだ結果, 剪断応力を受け, 比較的鋼素地に近い部分でクラックを発生するものと推察 される。

以上，述べてきたように，溶融Zn-5３0mass\%Al合金め っきでは, $\mathrm{Al}-\mathrm{Fe} ・ \mathrm{IMC}$ 中に形成される空陌がバルク組成の 融液を引き込み， $\mathrm{A} 1$ の拡散パスが短くなることにより， $\mathrm{Al}-\mathrm{Fe} \cdot \mathrm{IMC}$ 成長が促進されると考えられる。そして, $\mathrm{Al}-\mathrm{Fe} \cdot \mathrm{IMC}$ 合金層中の空隙の形成も，合金層中のZnが鋼素 地のフェライト粒界に拡散することに誘発されていると考 える。

\section{5. 結言}

アルミニウム濃度が5～30mass\%の溶融 $\mathrm{Zn}-\mathrm{Al}$ 合金めっき における短時間浸せき下での合金層成堆挙動を検討した。 得られた結果は以下の通りである。

( 1 )めつき浴温が $520^{\circ} \mathrm{C}$ 以上になると知時間の浸せきでも 合金層の成長が起こり，同じめっき浴温でも浴中のAl濃度 が高い方がその成壴は著しくなる。

( 2 ) 成表型合金層は, $\mathrm{Zn}$ を6.7 8.7at\%固溶する $\mathrm{Al}_{5} \mathrm{Fe}_{2}$ 相を主体としたAl-Fe系金属間化合物で，その空隙にZn濃 度が94〜95at\%の相が散在した構造を有している。 $\mathrm{Al}_{5} \mathrm{Fe}_{2}$ 相自身は銅板面に対して垂淔に一方向成言しており，これ は溶融アルミニウムめっきの合金層成長と類似している。

( 3 ）溶融 $Z n-5 \sim 30 \mathrm{mass} \% \mathrm{Al}$ 合金めっきの合金層成長は, 銅菜地のフェライト粒界にZnが拡散した後を追いかけて $\mathrm{Al}-\mathrm{Fe} \cdot \mathrm{IMC}$ 優先成产するのが特徵で，このZnの粒界拡散 がAl-Fe・IMCの成長を促進していると考えられる。

\section{文献}

1) K.L.Lin, J.K.Ho, C.S.Jong and J.T.Lee: Physical Metallurgy of Zinc Coated Steel, ed. by A.R.Marder, (1993), p.89 [Mineral \& Materials Soc.]

2) K.Marques and H.Goldstein: Physical Metallurgy of Zinc Coated Steel, ed. by A.R.Marder, (1993), p.111 [Mineral \& Materials Soc.]

3 ) A.R.P.Ghuman and J.I.Goldstein: Metall. Trans., 2 (1971), p. 2903

4 ) R.G.Caceres, C.A.Hotham, J.A.Spittle and R.D.Jones: Materials Sci. \& Tech., 2 (1986), p.871

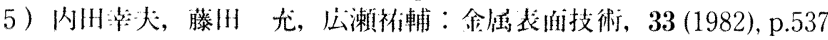

6 ) J.H.Selverian, A.R.Marder and M.R.Notis: Metall. Trans.A, 19A (1988), p.1193

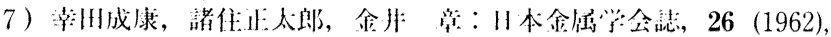
p.764

8 ）西田恵三：金属衣洫技術， 15 (1964), p.498

9) T.Heumann and S.Dittrich : Z.Metallk., 50 (1959), p.617

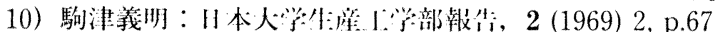

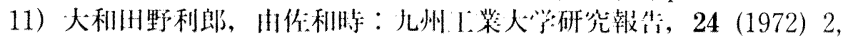
p. 21

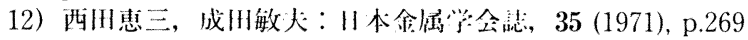

13）たとえば, W.Rostoker, J.M.McCaughey and H.Markus : Embrittlement by Liquid Metals, (1960), [Reinhold]

14) L.Allegra, R.G.Hart and H.E.Townsend: Metall. Trans. A, 14A (1983), p.401 